\title{
Mutant p53 protein in serum could be used as a molecular marker in human breast cancer
}

\author{
G.A.BALOGH ${ }^{1,7}$, D.A. MAILO ${ }^{8}$, M.M.CORTE ${ }^{2,4}$, P. RONCORONI ${ }^{2,4}$, H. NARDI $^{2-4}$, E. VINCENT ${ }^{4-6}$, \\ D. MARTINEZ ${ }^{4,5}$, M.E.CAFASSO ${ }^{2}$, A. FRIZZA ${ }^{2,4}$, G. PONCE ${ }^{2}$, E. VINCENT ${ }^{4-6}$, E. BARUTTA ${ }^{2}$, \\ P. LIZARRAGA ${ }^{2,4}$, G. LIZARRAGA ${ }^{2,4}$, C. MONTI $^{2}$, E. PAOLILLO ${ }^{2,4}$, R. VINCENT ${ }^{4,6}$, \\ R. QUATROQUIO ${ }^{4,5}$, C. GRIMI ${ }^{2,4,5}$, H. MATURI ${ }^{2,4-6}$, M. AIMALE $^{4}$, C. SPINSANTI ${ }^{2}$, \\ H. MONTERO ${ }^{2}$, J. SANTIAGO ${ }^{4,5}$, L. SHULMAN ${ }^{2}$, M. RIVADULLA ${ }^{2,4,5}$, M. MACHIAVELLI $^{5}$,

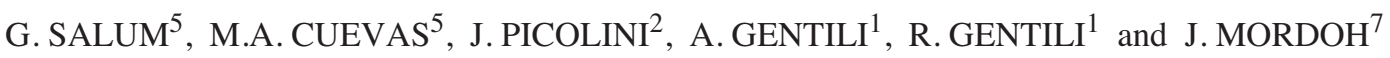 \\ ${ }^{1}$ Instituto de Analistas Clinicos Asociados (IACA); ${ }^{2}$ Sanatorio Privado del Sur; ${ }^{3}$ Hospital Interzonal Dr Jose Penna; \\ ${ }^{4}$ Hospital Regional Español; ${ }^{5}$ Hospital Dr Leonidas Lucero; ${ }^{6}$ Hospital de la Asociacion Medica, Bahía Blanca; \\ ${ }^{7}$ Instituto de Investigaciones Bioquimicas Luis F. Leloir, Fundación Campomar, Buenos Aires, Argentina; \\ ${ }^{8}$ Fox Chase Cancer Center, Philadelphia, PA, USA
}

Received October 25, 2005; Accepted December 2, 2005

\begin{abstract}
. p53 wild-type is a tumor suppressor gene involved in DNA gene transcription or DNA repair mechanisms. When damage to DNA is unrepairable, p53 induces programmed cell death (apoptosis). The mutant p53 gene is the most frequent molecular alteration in human cancer, including breast cancer. Here, we analyzed the genetic alterations in p53 oncogene expression in 55 patients with breast cancer at different stages and in 8 normal women. We measured by ELISA assay the serum levels of p53 mutant protein and p53 antibodies. Immunohistochemistry and RT-PCR using specific p53 primers as well as mutation detection by DNA sequencing were also evaluated in breast tumor tissue. Serological p53 antibody analysis detected $0 / 8(0 \%), 0 / 4(0 \%)$ and $9 / 55$ $(16.36 \%)$ positive cases in normal women, in patients with benign breast disease and in breast carcinoma, respectively. We found positive p53 mutant in the sera of $0 / 8(0.0 \%)$ normal women, 0/4 (0\%) with benign breast disease and 29/55 $(52.72 \%)$ with breast carcinoma. Immunohistochemistry evaluation was positive in 29/55 (52.73\%) with mammary carcinoma and $0 / 4(0 \%)$ with benign breast disease. A very good correlation between p53 mutant protein detected in serum and p53 accumulation by immunohistochemistry $(83.3 \%$ positive in both assays) was found in this study. These data suggest that detection of mutated p53 could be a useful serological marker for diagnostic purposes.
\end{abstract}

Correspondence to: Dr Gabriela Balogh, Fox Chase Cancer Center, 333 Cottman Avenue, Philadelphia, PA 19111, USA

E-mail: ga_balogh@fccc.edu

Key words: breast cancer, tumor protein p53, p53 mutant in serum

\section{Introduction}

A variety of molecular genetic changes have been described in breast cancer. Oncogene and tumor suppressor gene alterations have been studied in an attempt to define the molecular correlation between prognosis and the clinical behavior of breast cancer phenotype (1). Among those, the p53 tumor suppressor gene has become the focus of intensive studies. The current and most powerful model of wild-type p53 function is one in which p53 monitors the genome for DNA damage (2). After treatment of cells with DNA damaging agents, p53 protein levels are increased by post-translational stabilization and can transactivate various genes that may be related to cell-cycle arrest or apoptosis (3). Arrest of cell-cycle progression following DNA damage is thought to represent a basic protective mechanism preventing replication of damaged template DNA. If damage is irreparable, the cell may be driven to apoptotic pathway, thus preventing replication of defective cells. Mutations in the p53 tumor suppressor gene are the most frequent known genetic alterations in all human cancers (4). Most of the biologically significant mutations impair the ability of p53 to participate in the maintenance of genomic stability. Consequently, tumors lacking normal p53 might be expected to be prone to deleterious mutations and to be more aggressive clinically. Many studies have examined the association between breast cancer prognosis and p53 protein expression in tumor cells (5-13). The use of immunohistochemistry (IHC) was based on the fact that missense mutations usually result in an increased half-life of the protein product and a consequent accumulation of the mutant p53 protein in the nucleus. Another different methodology is the detection of p53-specific antibodies, which explains the discrepant results for the p53accumulation in the same tumor type $(5,8-12)$. Our purpose here was to study the relationship between p53 at protein and antibody levels and IHC in 55 cases of human breast tumor at different stages of the disease. These results revealed that the 
level of p53 mutant protein in the serum of breast cancer patients directly correlated with $\mathrm{p} 53$ accumulation and with the presence of mutations. These findings may be important in breast cancer detection and the analysis of p53 mutant protein could be used as a diagnostic tool and for differentiating benign and malignant breast disease before surgery.

\section{Materials and methods}

Patients. From August 1999 to August 2000, 55 patients with mammary pathology were analyzed from the following hospitals: Sanatorio Privado del Sur, Interzonal Dr Jose Penna, Regional Español, Dr Leonidas Lucero, and Hospital de la Asociación Médica, Bahía Blanca, Argentina. Serum and breast tissue from patients with histologically diagnosed breast disease were available for analysis. The serum was collected preoperatively and was stored at $-80^{\circ} \mathrm{C}$, and the breast tissue was kept in liquid nitrogen until it was processed. Eight serum samples from normal patients without breast disease or any breast cancer history were utilized as negative control for the serological assays. The median age of all patients was 55, from 28 to 91 years (Table I).

Serological analysis. We quantified the presence of p53 autoantibodies from the serum of all of the patients employing the p53 ELISA ${ }^{\text {PLUS }}$ (auto-antibody) kit (Oncogene Research Products, Cambridge MA, USA). The kit was designed to measure circulating antibodies to p53 in human serum samples. We employed the control serum provided by the manufacturer. The results were expressed in O.D. units and were categorized as negative or positive.

We also quantified the p53 mutant protein level from the serum using a sandwich enzyme linked immuno-absorbent assay (ELISA) with microtrite plates coated with recombinant human p53 protein expressed in Escherichia coli [p53 ELISA kit (mutant-selective), Oncogene Research Products]. The ELISA test was suitable for the quantitative determination of mutant p53 protein, the antibodies utilized in this assay kit reacted with an epitope exposed on human and most mammalian mutant $\mathrm{p} 53$ proteins but not on wild-type p53, thus making the assay mutant-selective. The results were expressed in O.D. units and were categorized as negative or positive. Eight serum samples from normal women without any breast disease or any familial cancer history were utilized as negative control.

Histology. Human breast tumor sections $(5 \mu \mathrm{m})$ were cut from formalin-fixed, paraffin-embedded tissue from all of the patients entered in this study. Nuclear grade was defined as grades I-III according to previously established criteria $(13,14)$. The histological classification and the nuclear grade were performed by a medical pathologist. Each tissue was cut in duplicate for performing the immunohistochemistry study of p53.

Immunohistochemistry. Tumor cell staining for $\mathrm{p} 53$ protein was performed using mouse monoclonal DO-1 antibody (Oncogene Research Products. All sections were de-paraffinaized in xylene, rehydrated through a graded series of alcohols, and washed in phosphate-buffered saline. This buffer was used
Table I. Histology, tumor stage and age of the patients.

\begin{tabular}{|c|c|c|c|c|}
\hline $\begin{array}{l}\text { Pts. } \\
\text { no. }\end{array}$ & Pts. ID & $\begin{array}{c}\text { Age } \\
\text { (years) }\end{array}$ & Tumor stage & Histology \\
\hline 1 & $2000-08$ & 52 & Benign & Mastopathy \\
\hline 2 & $2000-13$ & 58 & Benign & Mastopathy \\
\hline 3 & $2000-23$ & 68 & Benign & Fibroadenoma \\
\hline 4 & $2000-33$ & 76 & Benign & s.n.p \\
\hline 5 & $2000-49$ & 46 & Benign & HAD \\
\hline 6 & $2000-55$ & 48 & Benign & Fibroquistic disease \\
\hline 7 & $2000-11$ & 55 & ISC & IDC w.d \\
\hline 8 & $2000-25$ & 69 & ISC & IDC $\mathrm{w} . \mathrm{d}$ \\
\hline 9 & $2000-30$ & 72 & Phylloides tumor & Phylloides tumor \\
\hline 10 & $2000-41$ & 28 & w/od & s.n.p \\
\hline 11 & $2000-42$ & 28 & w/od & s.n.p \\
\hline 12 & $2000-47$ & 37 & w/od & s.n.p \\
\hline 13 & $2000-01$ & 49 & I & IDC s.d \\
\hline 14 & $2000-02$ & 49 & I & IDC 1.d \\
\hline 15 & $2000-03$ & 50 & I & IDC s.d \\
\hline 16 & $2000-04$ & 50 & I & IDC w.d \\
\hline 17 & $2000-05$ & 51 & I & IDC w.d \\
\hline 18 & $2000-06$ & 51 & I & IDC 1.d \\
\hline 19 & $2000-10$ & 54 & I & IDC s.d \\
\hline 20 & $2000-14$ & 59 & I & IDC s.d \\
\hline 21 & $2000-19$ & 60 & I & IDC s.d \\
\hline 22 & $2000-20$ & 61 & I & IDC w.d \\
\hline 23 & $2000-32$ & 75 & I & IDC 1.d \\
\hline 24 & $2000-37$ & 80 & I & IDC s.d \\
\hline 25 & $2000-38$ & 80 & I & IDC s.d \\
\hline 26 & $2000-46$ & 36 & I & IDC w.d \\
\hline 27 & $2000-48$ & 45 & I & IDC s.d \\
\hline 28 & $2000-53$ & 48 & I & IDC s.d \\
\hline 29 & $2000-54$ & 48 & I & IDC s.d \\
\hline 30 & $2000-24$ & 68 & Ia & IDC 1.d \\
\hline 31 & $2000-28$ & 71 & Ia & IDC w.d \\
\hline 32 & $2000-12$ & 57 & II & IDC 1.d \\
\hline 33 & $2000-29$ & 72 & II & IDC 1.d \\
\hline 34 & $2000-31$ & 73 & II & IDC 1.d \\
\hline 35 & $2000-34$ & 76 & II & IDC s.d \\
\hline 36 & $2000-36$ & 77 & II & IDC w.d \\
\hline 37 & $2000-43$ & 31 & II & IDC s.d \\
\hline 38 & $2000-52$ & 47 & II & IDC 1.d \\
\hline 39 & $2000-07$ & 52 & III & IDC 1.d \\
\hline 40 & 2000-09 & 52 & III & IDC s.d \\
\hline 41 & $2000-15$ & 60 & III & IDC s.d \\
\hline 42 & $2000-16$ & 60 & III & ILC s.d \\
\hline 43 & $2000-17$ & 60 & III & IDC s.d \\
\hline 44 & $2000-18$ & 60 & III & IDC s.d \\
\hline 45 & $2000-27$ & 70 & III & IDC 1.d \\
\hline 46 & $2000-35$ & 77 & III & IDCs.d \\
\hline 47 & $2000-39$ & 90 & III & IDC s.d \\
\hline 48 & $2000-44$ & 32 & III & IDC 1.d \\
\hline 49 & $2000-45$ & 32 & III & IDC s.d \\
\hline 50 & $2000-50$ & 47 & III & IDC 1.d \\
\hline 51 & $2000-51$ & 47 & III & IDC s.d \\
\hline 52 & $2000-21$ & 66 & IIIa & IDC s.d \\
\hline 53 & $2000-22$ & 66 & IIIa & IDC s.d \\
\hline 54 & $2000-26$ & 70 & IIIb & IDC 1.d \\
\hline 55 & $2000-40$ & 91 & IIIb & IDC s.d \\
\hline
\end{tabular}


Table II. Expression of anti p53-antibodies and mutant p53 protein in serum and $\mathrm{p} 53$ protein in the breast tissue from all patients employed in this study.

\begin{tabular}{|c|c|c|c|c|}
\hline $\begin{array}{l}\text { Pts. } \\
\text { no. }\end{array}$ & Pts. ID & $\begin{array}{c}\text { Anti } \\
\text { p53-Ab }\end{array}$ & $\begin{array}{c}\text { Mutant } \\
\text { p53 protein }\end{array}$ & $\begin{array}{c}\text { p53 accum. } \\
\text { (IHC) }\end{array}$ \\
\hline 1 & 2000-08 & $0.086 \pm 0.002$ & $0.011 \pm 0.001$ & Negative \\
\hline 2 & $2000-13$ & $0.154 \pm 0.052$ & $0.013 \pm 0.003$ & Negative \\
\hline 3 & $2000-23$ & $0.005 \pm 0.001$ & $0.022 \pm 0.001$ & Negative \\
\hline 4 & $2000-33$ & $0.896 \pm 0.123$ & $0.069 \pm 0.001$ & Negative \\
\hline 5 & $2000-49$ & $0.099 \pm 0.009$ & $0.081 \pm 0.005$ & Negative \\
\hline 6 & $2000-55$ & $0.3401 \pm 0.098$ & $0.081 \pm 0.004$ & Negative \\
\hline 7 & $2000-11$ & $0.093 \pm 0.002$ & $0.088 \pm 0.053$ & Negative \\
\hline 8 & $2000-25$ & $0.005 \pm 0.001$ & $0.113 \pm 0.006$ & Negative \\
\hline 9 & $2000-30$ & $0.093 \pm 0.012$ & $0.117 \pm 0.003$ & Negative \\
\hline 10 & $2000-41$ & $0.089 \pm 0.013$ & $0.117 \pm 0.001$ & N.D. \\
\hline 11 & $2000-42$ & $0.029 \pm 0.001$ & $0.119 \pm 0.008$ & N.D. \\
\hline 12 & $2000-47$ & $0.42 \pm 0.083$ & $0.12 \pm 0.004$ & N.D. \\
\hline 13 & $2000-01$ & $0.04 \pm 0.005$ & $0.12 \pm 0.004$ & Negative \\
\hline 14 & $2000-02$ & $0.215 \pm 0.023$ & $0.121 \pm 0.005$ & Negative \\
\hline 15 & $2000-03$ & $0.142 \pm 0.009$ & $0.129 \pm 0.003$ & Negative \\
\hline 16 & 2000-04 & $0.182 \pm 0.003$ & $0.138 \pm 0.074$ & Negative \\
\hline 17 & $2000-05$ & $0.142 \pm 0.003$ & $0.135 \pm 0.054$ & Negative \\
\hline 18 & $2000-06$ & $0.122 \pm 0.003$ & $0.145 \pm 0.076$ & Negative \\
\hline 19 & $2000-10$ & $0.005 \pm 0.001$ & $0.135 \pm 0.082$ & Negative \\
\hline 20 & $2000-14$ & $0.992 \pm 0.005$ & $0.136 \pm 0.032$ & Negative \\
\hline 21 & 2000-19 & $0.811 \pm 0.013$ & $0.137 \pm 0.052$ & Negative \\
\hline 22 & $2000-20$ & $0.811 \pm 0.013$ & $0.139 \pm 0.007$ & Negative \\
\hline 23 & $2006-32$ & $0.005 \pm 0.001$ & $0.139 \pm 0.034$ & Negative \\
\hline 24 & $2000-37$ & $0.405 \pm 0.068$ & $0.144 \pm 0.004$ & Negative \\
\hline 25 & $2000-38$ & $0.075 \pm 0.012$ & $0.146 \pm 0.004$ & Negative \\
\hline 26 & $2000-46$ & $0.252 \pm 0.056$ & $0.165 \pm 0.005$ & Negative \\
\hline 27 & $2000-48$ & $0.319 \pm 0.032$ & $0.195 \pm 0.098$ & Positive + \\
\hline 28 & $2000-53$ & $0.05 \pm 0.0034$ & $0.199 \pm 0.034$ & Positive + \\
\hline 29 & $2000-54$ & $0.096 \pm 6.009$ & $0.201 \pm 0.075$ & Positive + \\
\hline 30 & $2000-24$ & $0.005 \pm 0.001$ & $0.202 \pm 0.029$ & Positive + \\
\hline 31 & $2000-28$ & $0.021 \pm 0.001$ & $0.211 \pm 0.034$ & Positive + \\
\hline 32 & $2000-12$ & $0.245 \pm 0.057$ & $0.212 \pm 0.039$ & Positive + \\
\hline 33 & $2000-29$ & $0.054 \pm 0.066$ & $0.221 \pm 0.084$ & Positive + \\
\hline 34 & $2000-31$ & $0.005 \pm 0.001$ & $0.224 \pm 0.013$ & Positive + \\
\hline 35 & $2000-34$ & $0.267 \pm 0.013$ & $0.231 \pm 0.032$ & Positive + \\
\hline 36 & $2000-36$ & $0.069 \pm 0.009$ & $0.276 \pm 6.095$ & Positive + \\
\hline 37 & $2000-43$ & $0.269 \pm 0.023$ & $0.319 \pm 0.096$ & Positive + \\
\hline 38 & $2000-52$ & $0.205 \pm 0.056$ & $0.341 \pm 0.054$ & Positive + \\
\hline 39 & $2000-07$ & $0.275 \pm 6.034$ & $0.341 \pm 0.054$ & Positive + \\
\hline 40 & $2000-09$ & $0.84 \pm 0.005$ & $0.351 \pm 0.039$ & Positive ++ \\
\hline 41 & $2000-15$ & $0.059 \pm 0.064$ & $0.367 \pm 0.075$ & Positive ++ \\
\hline 42 & $2000-16$ & $0.093 \pm 0.002$ & $0.367 \pm 0.007$ & Positive ++ \\
\hline 43 & $2000-17$ & $0.052 \pm 0.007$ & $0.379 \pm 0.002$ & Positive ++ \\
\hline 44 & $2066-18$ & $0.26 \pm 0.012$ & $0.382 \pm 0.021$ & Positive ++ \\
\hline 45 & $2000-27$ & $0.078 \pm 0.008$ & $0.411 \pm 0.002$ & Positive ++ \\
\hline 46 & $2000-35$ & $0.018 \pm 0.001$ & $0.41 \pm 0.0034$ & Positive +++ \\
\hline 47 & $2000-39$ & $0.305 \pm 6.023$ & $0.475 \pm 0.032$ & Positive +++ \\
\hline 48 & $2000-44$ & $0.095 \pm 0.006$ & $0.508 \pm 0.093$ & Positive +++ \\
\hline 49 & $2000-45$ & $0.008 \pm 0.002$ & $0.617 \pm 0.098$ & Positive +++ \\
\hline 50 & $2000-50$ & $0.041 \pm 0.008$ & $0.713 \pm 0.096$ & Positive +++ \\
\hline 51 & $2000-51$ & $0.084 \pm 0.003$ & $0.764 \pm 0.093$ & Positive +++ \\
\hline 52 & $2000-21$ & $0.09 \pm 0.008$ & $1.241 \pm 0.354$ & Positive +++ \\
\hline 53 & $2000-22$ & $0.148 \pm 0.067$ & $1.594 \pm 0.103$ & Positive +++ \\
\hline 54 & $2000-26$ & $0.01 \pm 0.008$ & $2.686 \pm 0.193$ & Positive +++ \\
\hline 55 & $2000-40$ & $0.095 \pm 0.005$ & $2.808 \pm 0.193$ & Positive +++ \\
\hline
\end{tabular}

for all subsequent washes. IHC using the streptavidin-biotinperoxidase method was performed on paraffin-embedded tissue using the anti-p53 mouse monoclonal antibody, DO-1 (diluted 1:100), which recognizes the N-terminus of the human p53 protein (amino acids 21-23). In addition, the antibody reacted with both wild-type and many mutant p53 proteins. In order to do semi-quantitative assessment, the IHC results were scored. We established that the immunohistochemical staining for nuclear p53 in $>10 \%$ of the tumor cells was interpreted as positive: $(+)$ between $10-25 \%$ of nucleus positives, $(++)$ between $25-50 \%$ and $(+++)$ between $50-100 \%$ of nuclear staining.

Statistical analysis. The frequency of p53 values $\geq$ cut-off and the frequency of p53 values < cut-off were compared to the different parameters by a Chi-square test $\left(\chi^{2}\right.$ test).

\section{Results}

Serological level of anti-p53 antibodies in breast cancer patients. We quantified the anti-p53 antibodies in sera from 55 patients with different tumor histology and grade using the commercial p53 ELISA ${ }^{\text {PLUS }}$ kit (auto-antibodies) (Oncogene Research Products). The auto-p53 antibodies were quantified using the O.D. and standard curve employing the control serum provided by the manufacturer. The cut-off value was established as O.D. (1 U) x 0.15, meaning $(1.78 \times 0.15=0.267)$. The critic range of values was determined as the cut-off $\pm 20 \%$, means $0.267 \pm 20 \%$; the critic range value are $0.214-0.305$. The positive values were $>0.305$ and negative values were $<0.214$. All the values between 0.214 and 0.305 were considered as critical values.

In Table II, we show the auto-p53 antibodies quantification in each patient that was measured by duplicate performed in independent experiments \pm SD. In Table II is indicated the patient number, the age (years), the tumor grade, histology, O.D. for the auto-p53 antibodies average of two measurements, $\mathrm{SD}$ and results considering the critical range indicated above.

Fig. 1 shows the auto-p53 antibody quantification (O.D.) in sera from 55 patients, the dashed rectangle indicates the critic range, all values $>0.305$ were considered positive, and all values $<0.214$ were considered negative for this assay. In Fig. 1, the insert (a) represents the standard curve of p53 antibodies using the control serum provide by the manufacturer at increased doses. Of 55 patients, 9 had a positive presence of p53 auto-antibodies in their serum (16.36\% with respect to the total number of patients) (Table II and Fig. 1). In addition, $7 / 55$ patients were in the critical range of detection $(12.73 \%)$; however, in 39 out of 55 patients, the presence of p53 autoantibodies was negative, 70.91\% (Table II and Fig. 1). All normal women utilized as control showed negative results for the presence of p53 auto-antibodies in their serum (data not shown).

Presence of mutant p53 protein in the sera of breast cancer patients. We quantified the presence of p53 mutant protein in the sera of 55 patients with breast cancer at different stages and with different histology, using the mutant p53 ELISA kit (Oncogene Research Products). The kit was suitable for the quantitative determination of mutant p53 protein. The anti- 


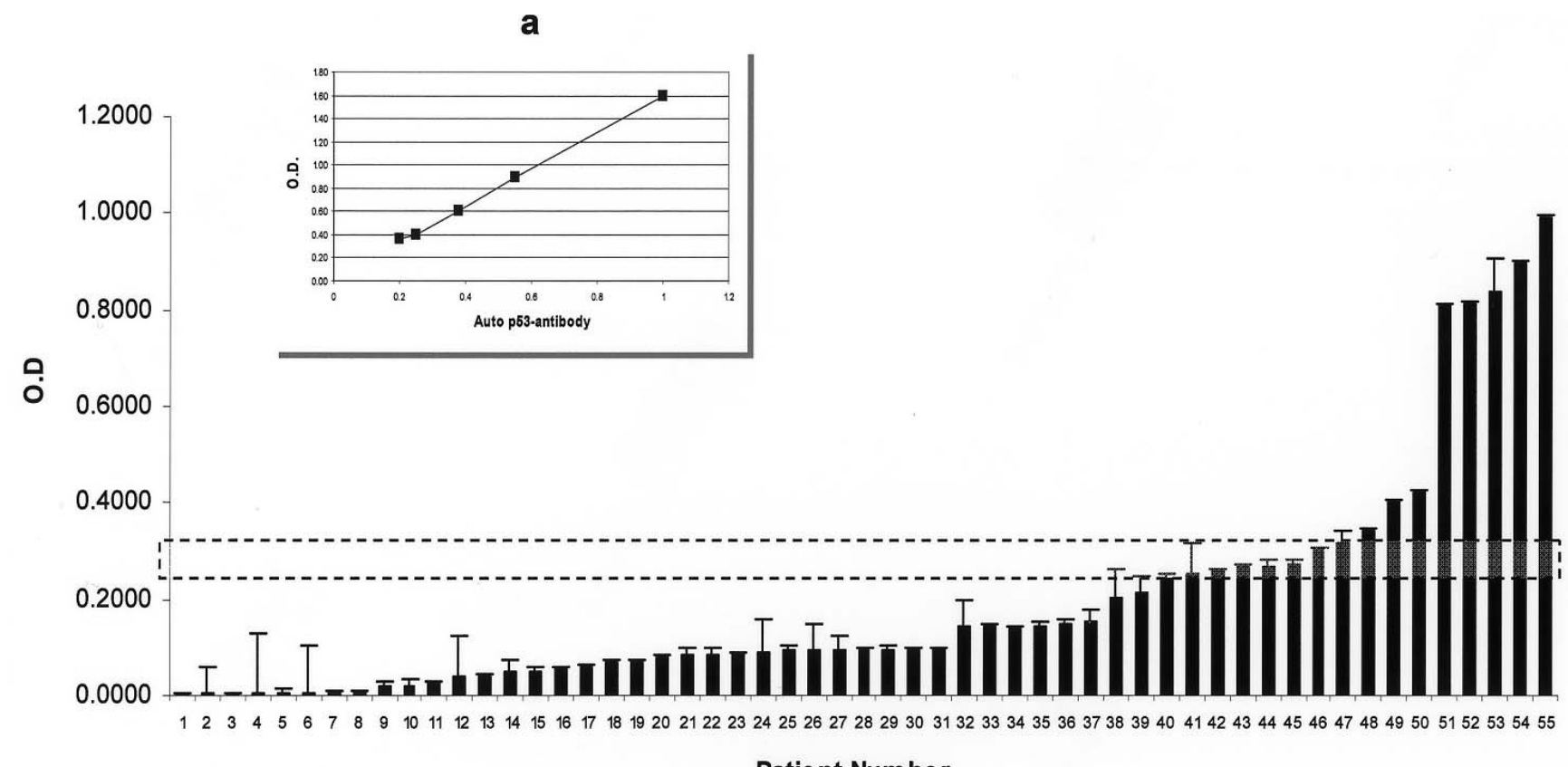

Patient Number

Figure 1. Quantification of auto-p53 antibodies in sera from breast cancer patients. The presence of p53 auto-antibodies from the sera of all of the patients was quantified employing the p53 ELISA ${ }^{\text {PLUS }}$ (auto-antibody) kit, the kit is designed to measure circulating antibodies to p53 in human serum samples. We employed the control serum provided by the manufacturer. The results were expressed in O.D. units and were categorized as negative, critic value or positive. The dashed rectangle indicates the critic value range (0.214-0.305), values $>0.305$ are considered positive and values $<0.214$ are considered negative. The internal figure (a) represents the standard curve of the auto-p53 antibody quantification. The cut-off value was calculated as O.D. $(1$ U) $\times 0.15=1.78 \times 0.15=0.267$, and the critic value was established as cut-off value $\pm 20 \%=0.214-0.302$. The positive values are $>0.302$ and the negative values are $<0.214$. The values in the range of 0.214-0.302 are considered critic values.

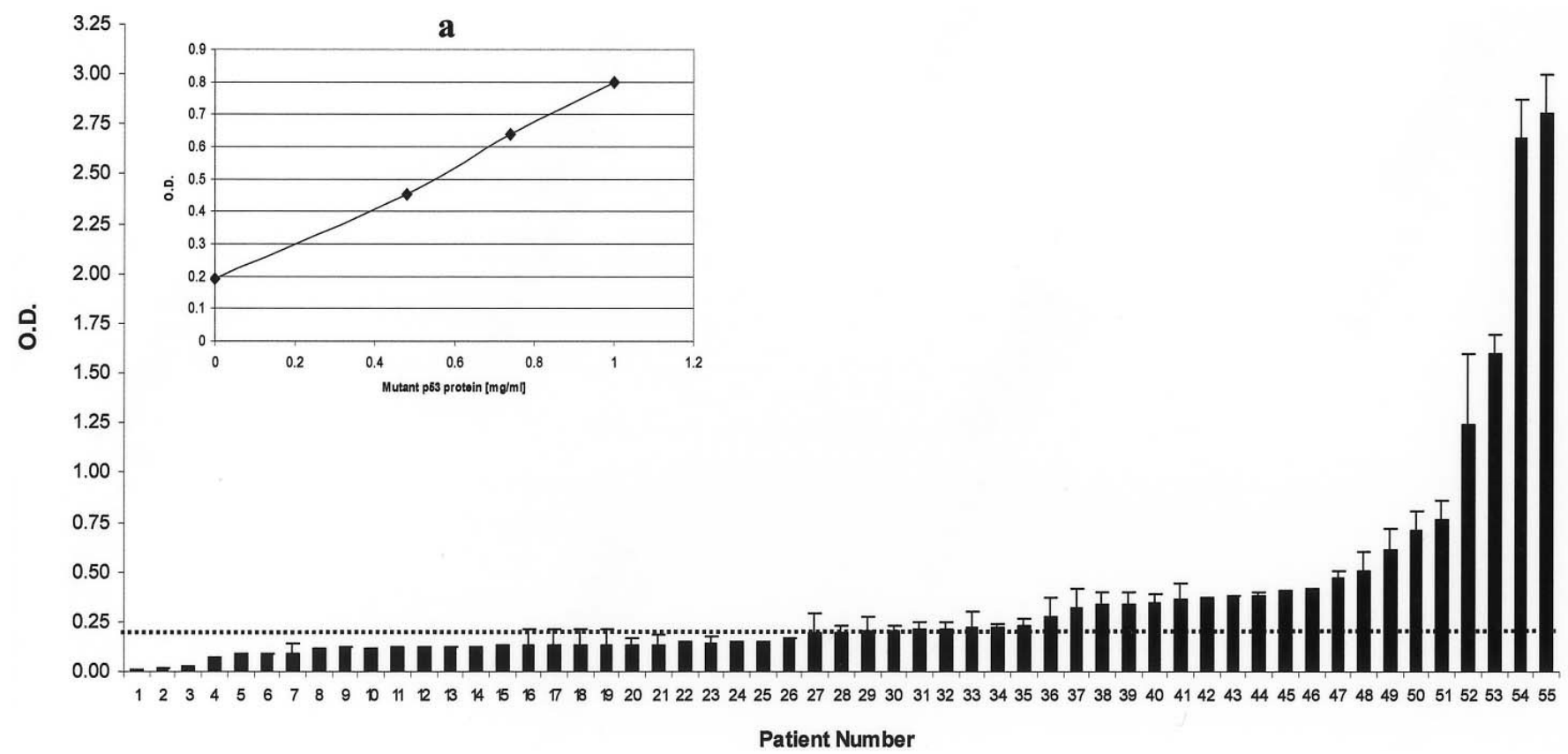

Figure 2. Quantification of mutant p53 protein in serum from breast cancer patients. The presence of mutant p53 protein in the serum was quantified employing the Mutant p53 ELISA kit (mutant-selective). The kit is designed to quantify the presence of mutant p53 protein. The antibodies used in this assay kit react only with an epitope exposed on human and most mammalian mutant p53 proteins but not on wild-type p53, thus making the assay mutant-selective. The results were expressed in O.D. units and were categorized as negative or positive. The dotted black line represents the cut-off value of 0.192 in O.D. The internal figure (a) represents the standard curve of the mutant $\mathrm{p} 53$ protein in $\mathrm{mg} / \mathrm{ml}$. The cut-off value was calculated as the value of O.D. at $0 \mathrm{mg} / \mathrm{ml}$ of mutant p53 protein, i.e. 0.192 (a). Each value represented is the average of two independent measurements \pm SD.

bodies utilized in this assay reacted with an epitope exposed on human mutant $\mathrm{p} 53$ protein, but not on wild-type p53, thus making the assay mutant-selective.
The cut-off value was established as the O.D. at $0 \mathrm{mg} / \mathrm{ml}$ p53 mutant protein; using the standard curve with the p53 mutant protein provided by the manufacturer, we calculated 

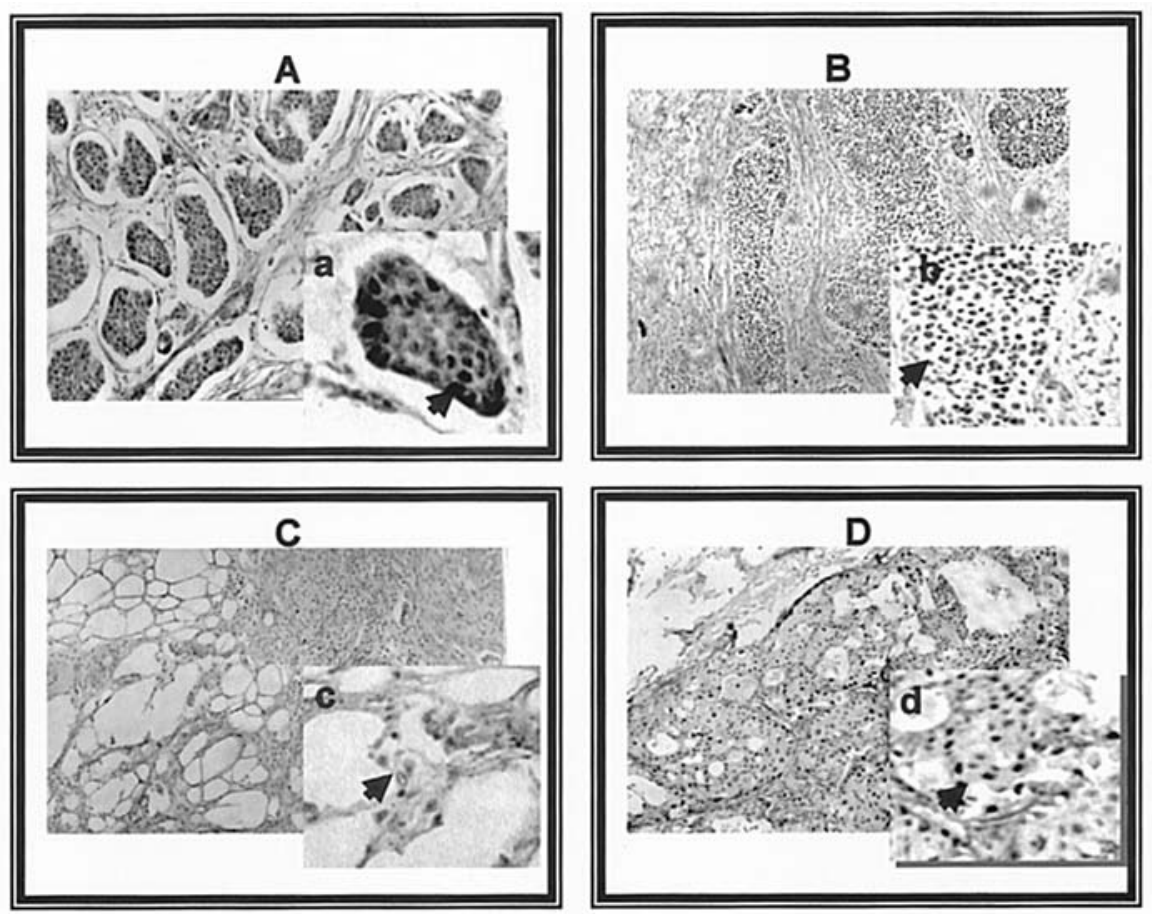

Figure 3. p53 protein expression in human breast cancer. Wild-type and mutant p53 protein were detected using the monoclonal DO-1 HPR-conjugated antibody (Oncogene Research Products, MA) at 1:100 dilution incubated overnight at $4^{\circ}$ C. (A) Patient no. 5 (positive +++ ), (a) amplification of A. (B) p53 expression in patient no. 43, (b) magnification at x40. (C)A negative case, (D) positive p53 expression corresponding to patient no. 39, and (d) magnification at x40.

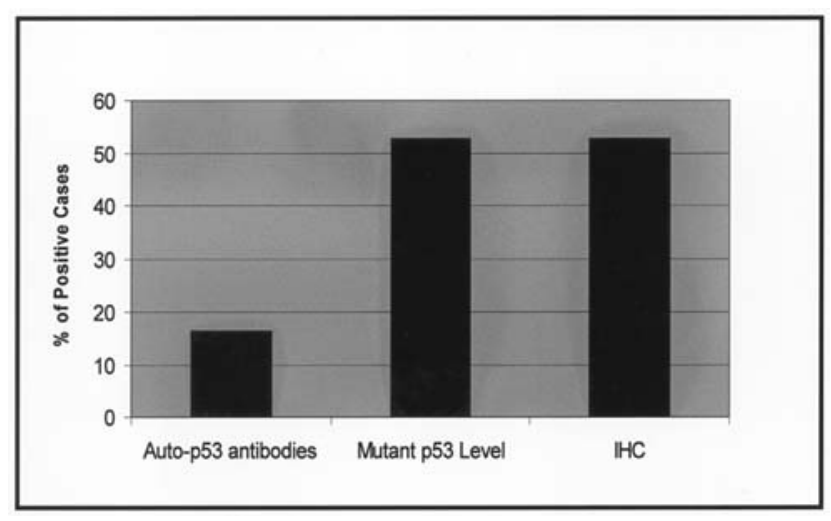

Figure 4. Total number of positive cases. The figure shows the total number of positive cases (expressed in \% with respect to the total number of patients) for the auto-p53 antibodies, mutant p53 level serum detection and p53 nuclear accumulation by immunohistochemistry.

the cut-off value as 0.192 (Fig. 2a). The positive values are the O.D. over the cut-off value and the negative values were under the cut-off value or 0.192 . In Table II, we show the patient number, age (years), tumor grade, histology, and the quantification of p53 mutant protein in serum determined by duplicate in two independent experiments \pm SD. Table II indicates the results considering the cut-off value (0.192).

Fig. 2 shows the quantification of p53 mutant protein in sera from 55 patients; in 29 out of 55, we found the presence of p53 mutant protein, $52.72 \%$ of the total number of patients. The other $47.28 \%$ were negative for the presence of p53 mutant protein. None of the normal women ( 8 in total) utilized as control had mutant $\mathrm{p} 53$ protein in their serum. p53 protein expression in breast cancer patients. Using immunohistochemistry we analyzed the presence of p53 wild-type and/or mutant protein in patients with different breast diseases and different stages of tumor and histology. We employed the mouse monoclonal DO-1 anti-p53 antibody HPR-conjugated (Oncogene Research Products) that recognizes amino-acids 21-25 in the amino-terminal domain of the protein. The antibody recognizes both the wild-type and the mutant p53 forms. We used a dilution of 1:100 and incubated the sections overnight at $4^{\circ} \mathrm{C}$.

Table II indicates the patient number, age, tumor stage, histology and the IHC results indicated as negative or positive; in the positive cases, the intensity of the reaction was also indicated as $(+),(++)$ or $(+++)$ depending on the number of cells stained: $(+)$ between $10 \%$ and $25 \%$ of nucleus positives, $(++)$ between $25 \%$ and $50 \%$, and $(+++)$ between $50 \%$ and $100 \%$ of nuclear staining. In Table II, ND indicates not determined, corresponding to patients without surgery.

We found p53 mutant protein expression in 29 out of 55 patients, $52.73 \%$ of the total number of patients. Of 55,22 (40\%) were negative, and 4/55 were not determined. Fig. 3 shows representative IHC results from breast cancer patients using the DO- 1 antibody diluted 1:100 and incubated overnight at $4^{\circ} \mathrm{C}$. Fig. $3 \mathrm{~A}$ represents the p53 protein expression of patient no. 5 (positive +++ ); Fig. $3 \mathrm{~B}$ represents the p53 protein expression of patient no. 43 (positive +++ ); Fig. $3 \mathrm{C}$ represents the absence of $\mathrm{p} 53$ protein expression in patient no. 28 ; and Fig. 3D represents the presence of $\mathrm{p} 53$ protein expression in patient no. 39 (positive ++ ).

Comparison of the presence of auto-p53 antibodies and p53 protein expression in serum by ELISA and IHC assay. Fig. 4 
A

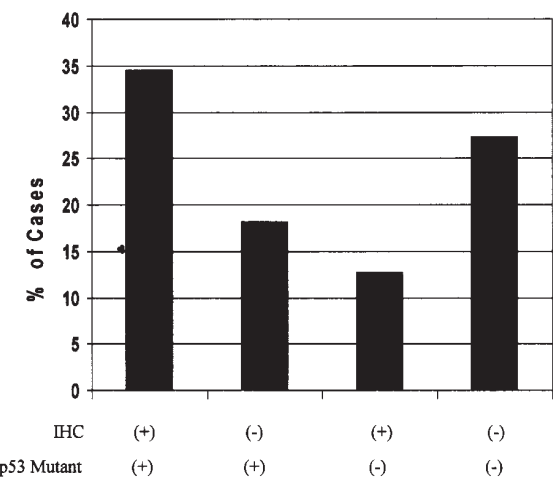

B

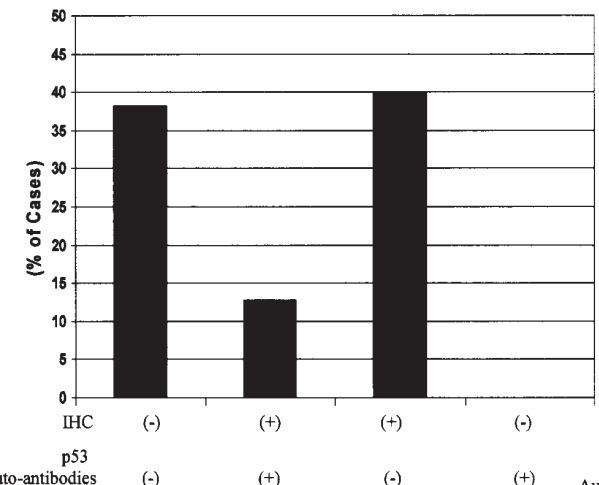

C

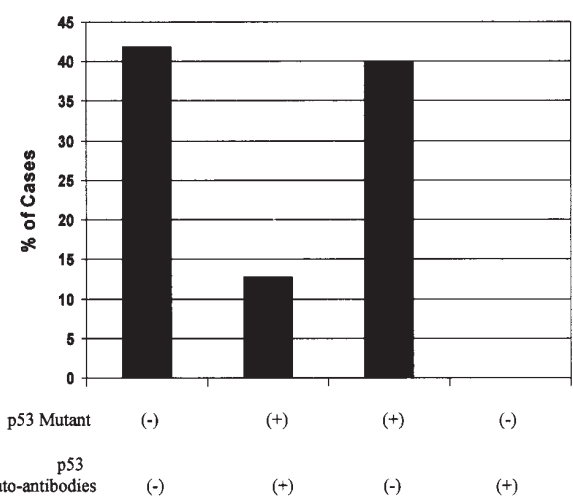

Figure 5. Positive cases comparison of $\mathrm{p} 53$ protein detection and its antibodies by IHC and by ELISA assays. (A) The \% of cases detected using immunohistochemistry and mutant p53 level in serum when both assays are positive, negative or have opposite results. (B) The \% of cases comparison between immunohistochemistry and the level of auto-p53 antibodies in serum when both assays are positive, negative or have opposite results. (C) The \% of cases that are positive, negative or have opposite results in the mutant p53 level compared with the level of auto-p53 antibodies.

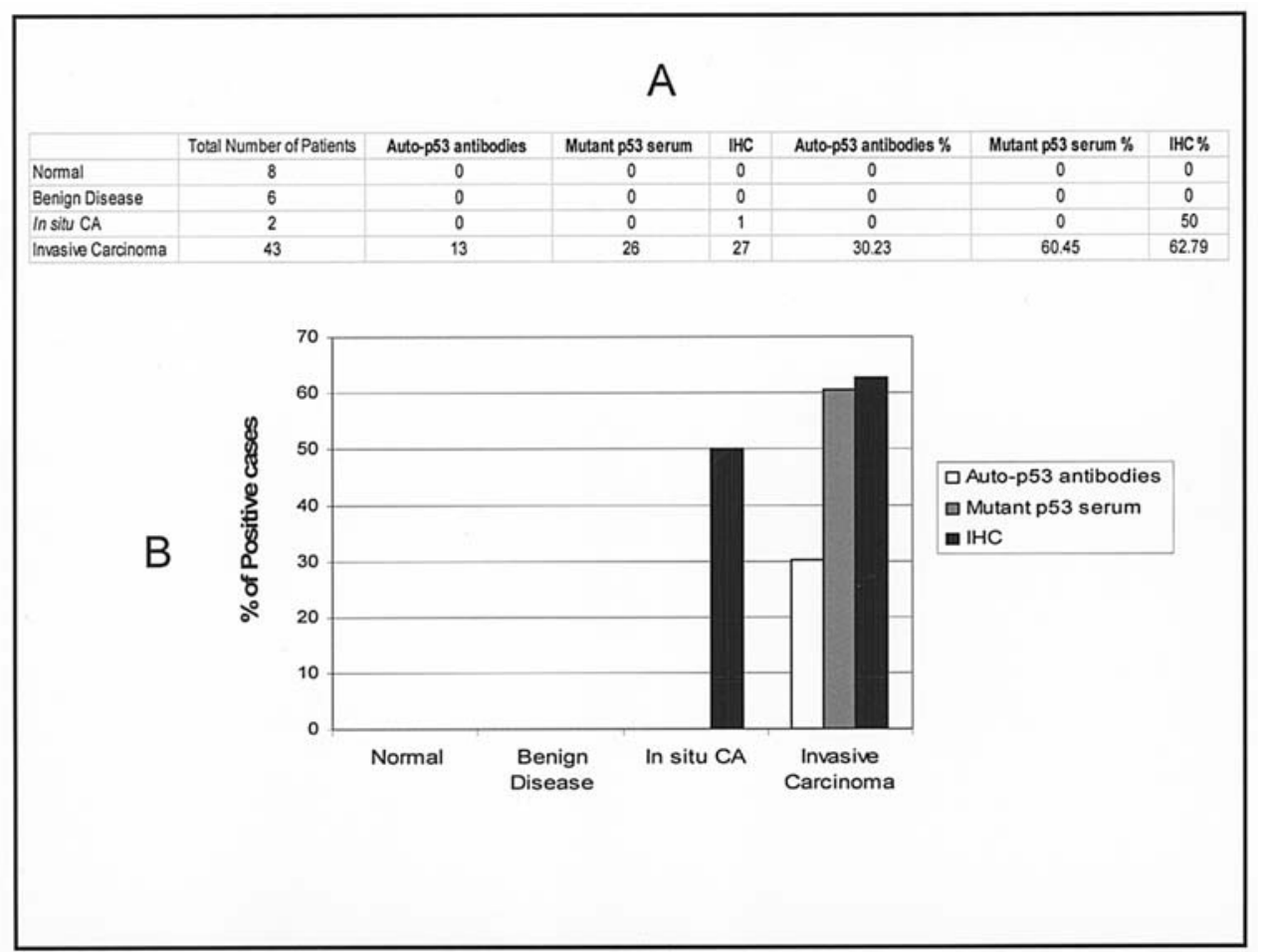

Figure 6. p53 protein expression histology tumor-dependent curve. (A) The total number of patients and positive cases by breast histology in the different assays. (B) The \% of positive cases (respect to total number of patients with the same histology) for p53 mutant protein expression by ELISA (gray columns) and by IHC (black columns) and the presence of auto-p53 antibodies in serum (white columns) in normal, benign, carcinoma in situ and invasive carcinomas (including ductal and lobular carcinomas).

shows the percentage of positive cases of auto-p53 antibodies, mutant $\mathrm{p} 53$ protein in serum and $\mathrm{p} 53$ protein expression by IHC in the 55 patients. A similar \% of positivity $(52.7 \%)$ was found for mutant $\mathrm{p} 53$ in serum and the presence of $\mathrm{p} 53$ protein mutant or wild-type by IHC in tissue sections using the DO-1 clone (Fig. 4). However, in only $16.36 \%$ of the total number of patients, auto-p53 antibodies were found in the sera (Fig. 4).

When comparing the two assays, we found that $34.8 \%$ and $27 \%$ of patients were positive and negative, respectively for both IHC and mutant p53 protein in serum (Fig. 5A). Therefore, $61.8 \%$ of patients had the same result in both studies and $29 \%$ had opposite results for both experiments; i.e. positive for $\mathrm{IHC}$ and negative for the mutant $\mathrm{p} 53$ protein in serum or vice versa (Fig. 5A).

When comparing the results of IHC and the presence of p53 auto-antibodies in serum, we found that in only $12 \%$ of patients were both assays positive, and $37 \%$ were negative (Fig. 5B). Also $40 \%$ of patients were positive for IHC and negative for the presence of auto-p53 antibodies.

When comparing the presence of mutant p53 protein and p53 auto-antibodies in serum, we found that $41.5 \%$ of patients were negative in both assays, and only $12 \%$ were positive in 
both (Fig. 5C). However, $40 \%$ had opposite results, meaning positive result in mutant $\mathrm{p} 53$ protein and negative result for the presence of p53 auto-antibodies (Fig. 5C).

Histology-dependent curve and p53 protein expression. Fig. 6 shows the number of positive cases for the presence of $\mathrm{p} 53$ auto-antibodies (blue columns), mutant p53 protein in serum (purple columns) and p53 protein by IHC (red columns) in serum from normal women, patients with benign disease, carcinoma in situ and patients with invasive carcinoma in stages I, II and III.

We analyzed the serum for mutant p53 protein and p53 auto-antibodies from 8 normal women, both assays gave negative results, i.e. $0 \%$ of normal patients had positive detection of mutant p53 or presence of antibodies in their serum (Fig. 6).

We did not detect the presence of mutant p53 protein or p53 antibodies in the sera of patients with benign disease (total 6 patients) (Fig. 6). Also, p53 protein expression by IHC was negative in these patients; $0 \%$ of patients with benign disease had positive assay (Table II).

We detected the presence of p53 protein by IHC in 1 out of 2 patients with in situ carcinoma (Fig. 6); $50 \%$ of in situ carcinoma patients showed positive expression of p53 by IHC but none of them showed the presence of mutant p53 protein or p53 auto-antibodies in their serum (Fig. 6).

We analyzed the p53 expression in 43 patients with invasive carcinoma (I.C.) (Table II). Thirteen out of 43 patients with I.C. (30.23\%) showed a positive presence of p53 autoantibodies, 26/43 (60.45\%) showed a presence of mutant p53 protein in serum and, in $62.79 \%(27 / 43)$, we found positive results by IHC for the presence of $\mathrm{p} 53$ in the tissue section.

\section{Discussion}

The development of molecular markers is needed to improve the diagnosis and assessment of tumor progression in breast cancer patients. Mutations of the p53 tumor suppressor gene, as well as overexpression of serum p53 antibodies and of p53 protein in tumor tissue, have been encountered in a variety of human malignancies (17).

p53-Ab was originally described by Crawford et al (16) in the serum of $9 \%$ of breast cancer patients using Western blotting. Using ELISA, more than 15 studies have been performed by Soussi in breast cancer (17). The frequency of p53-Abs in breast cancer ranges from 15 to $20 \%$ but the majority of these studies were performed either in Europe or in US. No study has been performed in South America and, specifically, in Argentina where the frequency of breast cancer is lower than those countries.

In the present study, we detected p53 auto-antibodies (p53-Abs) in 9 (16.36\%) of 55 sera patients with breast cancer. The presence of p53-Abs is strongly associated with tumors with $\mathrm{p} 53$ protein accumulation indicating that this immune response is triggered by the accumulation of p53 in the tumor as previously described in lung cancer (18). Patients with a more advanced disease (stage III) $(7 / 16,43.75 \%, \mathrm{p}<0.001)$ had a higher incidence of $\mathrm{p} 53$-Abs than in early disease (stage II) (with average of $0.0 \%$ ), although the difference was not statistically significant. However, we found a presence of
p53-Abs of $26.3 \%(5 / 19, \mathrm{p}<0.005)$ at stage $\mathrm{I}$, which is still lower than stage III. The presence of p53-Abs was not detected at very early stages like in situ carcinoma $(0 \%, 0 / 2)$, neither in patients with benign disease nor in normal patients.

The presence of p53-Abs strongly correlated with the presence of mutant p53 in serum and p53 accumulation by IHC. However, we found that the p53 auto-antibodies in serum from cancer patients were less sensitive but specific for breast cancer patients. p53-Ab is found predominantly in human cancer patients with a specificity of $96 \%$, but the sensitivity of such detection is only $30 \%$. Although p53 was not detected in sera from patients with non-malignant diseases (0.5-1\%) (17), the authors nevertheless suggested that serological testing for p53-Abs, despite its low positive results, can be regarded as a specific method to identify subgroups of patients with cancer (17).

The development of circulating serum antibodies against oncogene and tumor suppressor gene product represents an interesting model system for studying immune response in cancer patients. The simple and rapid ELISA procedure suggested the potential usefulness of p53-Abs in clinical implications. However, further investigations in larger prospective homogeneous series of patients are necessary before giving a definitive conclusion.

The overexpression of mutant $\mathrm{p} 53$ protein in breast cancer patients is usually evaluated in tumor tissue by immunohistochemical staining; however, the serum assay for p53 oncoproteins using ELISA can be easily and repeatedly performed because of its minimal invasiveness compared with assays using tissue materials $(18,19)$.

In the current study, the median serum level of mutant p53 protein showed significant difference compared to controls $(\mathrm{p}<0.001) ; 60.45 \%$ (26/43) positivity with invasive carcinoma, which demonstrated a positive elevation of mutant $\mathrm{p} 53$ protein in serum.

Our results correlate well with studies investigating the serum level of mutant p53 in cervical carcinoma patients performed by Sobti et al (20) and Oh et al (22), who reported that $61.5 \%$ of patients with invasive cervical carcinoma showed a positive elevation of mutant p53 in serum. However, there are very few results in breast cancer, Micelli et al demonstrated the presence of mutant $\mathrm{p} 53$ protein in serum in $23 \%$ of breast cancer patients without lymph node involvement and showed that the specificity of mutant p53 assay evaluated in 20 healthy controls was $100 \%$ (21).

In contrast with the $\mathrm{p} 53-\mathrm{Abs}$ results, the presence of mutant p53 protein in serum was predominantly found in invasive carcinomas at early stages (I or II) $(63.15 \%, 12 / 19$ at stage I, $\mathrm{p}<0.0001$; and $83.33 \%, 5 / 6$ at stage II, $\mathrm{p}<0.0001)$ rather than late stages (stage III, 50\% 8/16) (data not shown). Similar results were found for p53 accumulation; at early stages of invasive carcinoma, we detected higher expression than at late stages. The specificity of mutant p53 protein detection was $100 \%$ because it was negative in normal control serum and in patients with benign disease $(0 / 6,0 \%)$.

The lower positive rate of p53-Abs compared with the presence of mutant p53 protein in the serum of invasive carcinoma patients might have several explanations. First, the serum level of mutant p53 is liable to fluctuations based on the tumor lysis and clearance of p53 protein in blood 
because p53 is a nuclear protein (20). Second, additional uncharacterized protein-protein interactions between mutant p53 and other serum proteins might cause false-negative results in the detection of circulating antibody to mutant p53 protein, or the protein-protein interaction could mask the immune-system detection. Finally, one of the most important reasons could be that immune-system functionality is lower in patients with advanced stages of breast cancer compared with normal. However, we observed a very good correlation between the presence of p53-Abs and mutant p53 protein in serum and p53 accumulation.

The presence of mutant p53 protein in serum and p53 accumulation in the tissue was correlated with a low differentiation grade in invasive carcinomas $(63.64 \%$ and $72.73 \%$ for both assays, $\mathrm{p}<0.005$ ) rather than a higher differentiation level. However, the presence of p53-Abs was not significantly associated with tumor differentiation grade $(\mathrm{p}<0.06)$ in breast cancer patients (data not shown).

Several publications have demonstrated the presence of p53-accumulated protein by IHC in breast cancer. Al-Moundhri et al (23) found p53 overexpression in $41.7 \%$ of breast tumors examined with statistical significance. They also reported that p53 accumulation is related to poor tumor differentiation in human breast cancer (23).

In conclusion, serum mutant p53 protein was elevated in invasive breast carcinomas with a strong correlation with p53 accumulation detected by IHC. This data strongly indicated that the detection of mutant p53 in serum and p53 accumulation correlate and both tests are sensitive and specific for invasive breast carcinomas.

Although a prospective study with a large sample size is warranted, the presence of mutant $\mathrm{p} 53$ protein in serum could have potential usefulness as a biological marker of breast carcinoma especially for prediction of prognosis and followup after treatment.

Our findings indicate that mutant p53 in serum appears to be a new promising parameter to evaluate the cellular biology and prognosis of breast cancer from blood samples without surgery. The presence of mutant p53 protein can be an important tool in order to differentiate benign disease before performing surgery.

\section{Acknowledgments}

This work was supported by Instituto de Análisis Clinicos Asociados (IACA Lab), from Bahía Blanca, Argentina. Special thanks to Dr Roberto Gentili for his support.

\section{References}

1. Bieche I and Lidereau R: Genetic alterations in breast cancer. Genes Chromosomes Cancer 14: 227-251, 1995.

2. Lane DP: p53, guardian of the genome. Nature 358: 15-16, 1992.

3. Gottlieb TM and Oren M: p53 in growth control and neoplasia. Biochim Biophys Acta 1287: 77-102, 1996.
4. Hollstein M, Sidransky D, Vogelstein B and Harris C: p53 mutations in human cancers. Science 253: 49-53, 1991.

5. Varley JM, Brammar WJ, Lane DP, Swallow JE, Dolan C and Walker RA: Loss of chromosome 17p13 sequences and mutation of p53 in human breast carcinomas. Oncogene 6: 413-421, 1991.

6. Isola J, Visakorpi T, Holli K and Kallioniemi OP: Association of overexpression of tumor suppressor protein p53 with rapid cell proliferation and poor prognosis in node-negative breast cancer patients. J Natl Cancer Inst 84: 1109-1114, 1992.

7. Thor AD, Moore DH II, Edgerton SM, Kawasaki ES, Reihsaus E, Lynch HT, Marcus JN, Schwartz L, Chen LC, Mayall BH, et al: Accumulation of p53 tumor suppressor gene protein: an independent marker of prognosis in breast cancers. J Natl Cancer Inst 84: 845-855,1992.

8. Allred DC, Clark GM, Elledge R, Fuqua SA, Brown RW, Chamness GC, Osborne CK and McGuire WL: Association of p53 protein expression with tumor cell proliferation rate and clinical outcome in node-negative breast cancer. J Natl Cancer Inst 85: 200-206, 1993.

9. Thor AD and Yandell DW: Prognostic significance of p53 overexpression in node-negative breast carcinoma: preliminary studies support cautious optimism. J Natl Cancer Inst 85: 176-177, 1993.

10. Poller DN, Roberts EC, Bell JA, Elston CW, Blamey RW and Ellis IO: p53 protein expression in mammary ductal carcinoma in situ: relationship to immunohistochemical expression of estrogen receptor and c-erbB-2 protein. Hum Pathol 24: 463-468, 1993.

11. Silvestrini R, Benini E, Daidone MG, Veneroni S, Boracchi P, Cappelletti V, Di Fronzo G and Veronesi U: p53 as an independent prognostic marker in lymph node-negative breast cancer patients. J Natl Cancer Inst 85: 965-970, 1993.

12. Barnes DM, Dublin EA, Fisher CJ, Levison DA and Millis RR: Immunohistochemical detection of p53 protein in mammary carcinoma: an important new independent indicator of prognosis? Hum Pathol 24: 469-476, 1993.

13. Lagios MD: Pathologic practice standards for breast carcinoma: tumor size, reliable data, or miscues? J Am Coll Surg 196: 91-92, 2003.

14. Silverstein MJ and Lagios MD: Pathologic findings from the National Surgical Adjuvant Breast Project (NSABP) eight-year update of Protocol B-17. Cancer 88: 242-244, 2000.

15. pGEM $^{\circledR}$-T and pGEM $^{\circledR}$-T Easy Vector Systems Technical Manual \#TM042. Promega Corp.

16. Crawford LV, Pim DC and Bulbrook RD: Detection of antibodies against the cellular protein p53 in sera from patients with breast cancer. Int J Cancer 30: 403-408, 1982.

17. Soussi T: p53 antibodies in the sera of patients with various types of cancer: A review. Cancer Res 60: 1777-1788, 2000.

18. Choi J-H, Oh JY, Ryu SK, Kim SJ, Lee NY, Kim YS, et al: Detection of epidermal growth factor receptor in the serum of gastric carcinoma patients. Cancer 79: 1879-1883, 1997.

19. Oh MJ, Choi J-H, Kim IH, Lee YH, Huh JY, Park YK, et al: Detection of epidermal growth factor receptor in the serum of patients with cervical carcinoma. Clin Cancer Res 6: 4760-4763, 2000.

20. Sobti RC, Parashar K, Kaur R and Capalash N: Detection of human papillomavirus DNA, serum p53, and p53 antibodies in patients with cervical cancer. J Environ Pathol Toxicol Oncol 21: 79-85, 2002.

21. Micelli G, Donadeo A and Quaranta M: The p53 tumor suppressor gene. A preliminary clinical study in breast cancer patients. Cell Biophys 21: 25-31, 1992.

22. Oh MJ, Choi JH, Lee YH, Lee JK, Hur JY, Park YK, Lee KW, Chough SY and Saw HS: Mutant p53 protein in the serum of patients with cervical carcinoma: correlation with the level of serum epidermal growth factor receptor and prognostic significance. Cancer Lett 203: 107-112, 2004.

23. Al-Moundhri M, Nirmala V, Al-Mawaly K, Ganguly S, Burney I, Rizvi A and Grant C: Significance of p53, Bcl-2, and HER-2/ neu protein expression in Omani Arab females with breast cancer. Pathol Oncol Res 9: 226-231, 2003. 